\title{
The effect of rumen inert fat supplementation and protein degradability in starter and finishing diets on veal calf performance
}

\author{
C.W. Cruywagen ${ }^{1 \#}$, E.L. Lategan ${ }^{1,2}$ and L.C. Hoffman ${ }^{1}$ \\ ${ }^{1}$ Department of Animal Sciences, University of Stellenbosch, Private Bag X1, Matieland 7602, South Africa \\ ${ }^{2}$ Feedtek Association, P O Box 3263, Somerset West 7129, South Africa
}

\begin{abstract}
Thirty six Holstein bull calves were divided into six groups to determine the effect of protein degradability and rumen inert fat supplementation in starter and finishing diets on nutrient digestibility and veal production. Calves received low (LD) or high (HD) degradable protein diets, with or without rumen inert fat supplementation. Two commercial fat sources were used, Morlac (mlc) and Golden Flake (gf), included in the experimental diets at $2.5 \%$ of dry matter (DM). A commercial milk replacer was fed to all calves at $4 \mathrm{~L} /$ day for 42 days, followed by 2 L/day until weaning at 49 days of age. Starter diets were offered ad lib. from day 14 to 10 weeks of age and finishing diets ad lib. from 11 to 20 weeks of age. All calves were slaughtered at 20 weeks to determine carcass weight and dressing percentage. There were no significant differences in body weight gain or dry matter intake over the entire 20 week period. Feed conversion ratio (FCR) was improved when fat was supplemented to LD, but not to HD diets. The FCR (DM intake/kg gain) of LD, HD, LDmlc, HDmlc, LDgf and HDgf diets was 3.45, 3.44, 3.07, 3.81, 3.02 and 3.43, respectively. All 36 calves were used in a digestibility trial during week 18 of the study, using chromium oxide as a marker. Apparent digestibility values (\%) for LD, HD, LDmlc, HDmlc, LDgf and HDgf, respectively, were 61.7, 65.9, 75.4, 69.0, 75.5 and 67.2 for DM, 61.4, 61.6, 71.3, 68.2, 75.4 and 66.1 for crude protein and 58.6, 66.5, 76.0, 70.9, 78.4 and 70.8 for fat. Dry matter and fat digestibilities were significantly higher when fat was added to LD diets, but not to HD diets. The CP digestibility was significantly higher when fat was added to either the LD or the HD diets. It was concluded that rumen inert fat supplementation to calf diets appears to improve feed conversion ratio and DM and fat digestibilities, but only when added to low degradable protein diets and only after 10 weeks of age. Crude protein digestibility appears to improve with fat supplementation to either high or low degradable protein diets.
\end{abstract}

Keywords: Calves, nutrition, fat supplementation, protein degradability, nutrient digestibility, veal production

\#Corresponding author. E-mail: cwc@maties.sun.ac.za

\section{Introduction}

The crude protein (CP) content required in calf starter and finishing diets has been well documented (Stiles et al., 1974; Morrill \& Dayton, 1978; Fluharty \& Loerch, 1995). Early work established the minimum CP concentration in starter diets to be around 16\% (Leibholz \& Kang, 1973; Morrill \& Melton, 1973). Although many studies reported increased weight gains with diets containing more than $20 \%$ CP (Bartley, 1973; Schurman \& Kesler, 1974; Akayezu et al., 1994), most researchers doubt the advantage of more than $220 \mathrm{~g} / \mathrm{kg}$ CP in calf diets.

Although a wealth of information exists regarding the effect of ruminal degradability of dietary protein on milk production in dairy cows and weight gain in feedlot steers, very little research has been done on its value in the diets of young calves. It appears as if the degree of ruminal protein degradability does not have a beneficial effect on weight gains and feed conversion ratios in calves up to an age of about 12 weeks (Veen \& Vahl, 1984; Holtshausen \& Cruywagen, 2000). According to Amos (1986), increased undegradable protein (UDP) dietary levels had a beneficial effect on average daily gain (ADG) in calves from 16 weeks of age, while Holtshausen \& Cruywagen (2000) reported a positive effect of increased UDP levels in veal calf diets on feed conversion ratios between 11 and 20 weeks of age.

The inclusion of fat to increase energy density in dairy cow and feedlot diets is well established (Fluharty \& Loerch, 1997), but information regarding rumen inert fat supplementation of calf starter and finishing diets is limited. Gardner \& Wallentine (1972) reported positive growth responses by veal calves to the addition of tallow to starter rations, while Stiles et al. (1974) found a greater efficiency of feed conversion when tallow was added to calf diets from 12 weeks of age than when it was omitted. Waldern \& 
Fisher (1978) found no effect on feed conversion ratios with unprotected tallow in calf diets, while Fisher (1980) reported an increase in weight gains for calves receiving diets containing $20 \%$ vs. $10 \%$ (of DM) of a protected lipid source. No documented studies could be found where the effect of different dietary crude protein degradability levels and the inclusion of rumen inert fat sources were studied together. No literature could be found where rumen inert fat sources and different protein degradability levels were studied simultaneously. The current study was designed to investigate the effect of rumen inert fat supplementation at different CP degradability levels on calf performance in a grain-fed veal system.

\section{Materials and Methods}

Thirty-six Holstein bull calves, 2-5 days of age, were stratified according to initial weight and entered into six blocks. Calves in each block were randomly allocated to six treatments. Individual housing was provided in a semi-open barn in pens with wooden slatted floors and straw bedding. No extreme temperatures occurred during the trial period. The calves were weighed weekly during the starter period and fortnightly during the finishing period, following a $12 \mathrm{~h}$ fasting period. Dry matter intake (DMI) was determined weekly during the growth study and daily during the digestibility trial.

Calves in all treatments received $4 \mathrm{~L} /$ day of a commercial milk replacer (Denkavit, Johannesburg, South Africa) for the first 38 days of the trial, and then $2 \mathrm{~L} /$ day for another week. The milk replacer (220 g $\mathrm{CP}$ and $120 \mathrm{~g}$ fat $/ \mathrm{kg}$ dry matter (DM)) was prepared before each feeding by reconstituting with water $\left(39^{\circ} \mathrm{C}\right)$ at a concentration of $120 \mathrm{~g} / \mathrm{L}$. Starter diets were offered $a d$ lib. from 14 days until 10 weeks of age, and finishing diets ad lib. from 11 to 20 weeks of age. Starter and finishing diets were formulated to be isonitrogenous (180 and $140 \mathrm{~g} \mathrm{CP} / \mathrm{kg}$ DM, respectively), but differed in CP degradability and energy content.

Treatments were LD (low degradable protein) and HD (high degradable protein) each with, or without, rumen inert fat supplementation. Two rumen inert fat sources were used, viz. Morlac (Marine Oil Refiners, Dido Valley, Simon's Town, South Africa) and Golden Flake (Veekon, Silverton, Pretoria, South Africa). Both are calcium soaps of palm oil fatty acids and their fatty acid profiles are presented in Table 1 . The total mixed diets were pelleted and their physical and chemical composition is presented in Table 2.

Table 1 Fatty acid profiles (\% of DM) of rumen inert fat sources used in veal calf starter and finishing pellets

\begin{tabular}{ccc}
\hline Fatty acid & Morlac $^{1}$ & Golden Flake $^{2}$ \\
\hline C14:0 & 1.5 & 1.6 \\
C16:0 & 48.0 & 48.6 \\
C18:0 & 4.5 & 31.0 \\
C18:1 & 35.0 & 15.2 \\
C18:2 & 8.0 & 2.8 \\
\hline
\end{tabular}

${ }^{1}$ Specifications supplied by Marine Oils, Cape Town.

${ }^{2}$ Specifications supplied by Veekon, Pretoria.

During the fourth week of the trial, one calf in each of the LD Golden Flake and LD Morlac groups developed bloat and it was decided to provide lucerne hay (187 mg CP and $279 \mathrm{mg}$ crude fibre/ kg) ad lib. to all six groups in the starter phase from week five through 10 . This lucerne was fed in a coarse form and was in addition to the starter pellets described in Table 2. No further incidences of bloat were observed. No additional lucerne was fed in the finishing phase (week 11-20).

Dry matter and CP degradability values of the six pelleted starter- and finishing diets were determined in sacco by $24 \mathrm{~h}$ rumen incubation in three ruminally cannulated non-lactating Holstein cows (Table 3). All the feeds were milled in a Wyllie mill through a $2 \mathrm{~mm}$ screen. Five grams (as is) of each feed were weighed into dacron bags (pore size $53 \mu$ ) and the DM content of each feed determined separately. Two bags per diet were placed into a weighted nylon net bag and then into the rumens of the three cows. To prevent dacron bags from clogging together in the nylon bags, each nylon net bag was divided into three compartments, with four bags in each compartment. At the end of the incubation period all the bags were removed and washed thoroughly by hand under running water. The bags were dried in a forced draught oven at $55^{\circ} \mathrm{C}$ for $48 \mathrm{~h}$ and then weighed (Holtshausen \& Cruywagen, 2000).

All the calves were used in a digestibility trial at 18 weeks of age. Gelatine capsules containing $2.5 \mathrm{~g}$ of chromic III oxide were administered directly into the rumen twice daily, at 08:00 and 16:00, with the aid 
of a balling gun. The administration of the chromic III oxide started nine days prior to the collection period to ensure uniform excretion of the chromic III oxide in the faeces, and continued until the end of the faecal collection period. Faecal grab samples were collected twice daily at 08:00 and 16:00 for seven days and stored at $-20^{\circ} \mathrm{C}$. Total feed intake was also determined over this period. At the end of the collection period, faecal samples were composited for each calf, dried in a forced draught oven at $55{ }^{\circ} \mathrm{C}$, ground through a hammer mill (1 mm screen) and stored at $4{ }^{\circ} \mathrm{C}$ pending chemical analyses.

Feed and faecal samples were analysed for DM, Kjeldahl nitrogen, crude fibre and ash (AOAC, 1990) and lipid extraction by the acid hydrolysis procedure (AOAC No 922.06, 1996).

Table 2 Physical and chemical composition (dry matter basis) of veal calf starter and finishing pellets containing low (LD) or high (HD) levels of rumen degradable protein, with or without rumen inert fat sources $($ mlc $=$ Morlac; $\mathrm{gf}=$ Golden Flake $)$

\begin{tabular}{|c|c|c|c|c|c|c|c|c|c|c|c|c|}
\hline \multirow[t]{2}{*}{ Item } & \multicolumn{6}{|c|}{ Starter diets } & \multicolumn{6}{|c|}{ Finishing diets } \\
\hline & LD & HD & $\begin{array}{l}\mathrm{LD} \\
+\mathrm{mlc}\end{array}$ & $\begin{array}{l}\mathrm{HD} \\
+\mathrm{mlc}\end{array}$ & $\begin{array}{l}\text { LD } \\
+ \text { gf }\end{array}$ & $\begin{array}{l}\text { HD } \\
+ \text { gf }\end{array}$ & LD & HD & $\begin{array}{l}\text { LD } \\
+ \text { mlc }\end{array}$ & $\begin{array}{l}\mathrm{HD} \\
+\mathrm{mlc}\end{array}$ & $\begin{array}{l}\text { LD } \\
+ \text { gf }\end{array}$ & $\begin{array}{l}\text { HD } \\
+ \text { gf }\end{array}$ \\
\hline \multicolumn{13}{|l|}{ Physical composition } \\
\hline Maize meal (\%) & 60 & 50 & 57.5 & 47.5 & 47.5 & 47.5 & 63. 0 & 60.0 & 60.5 & 57.5 & 60.5 & 57.5 \\
\hline Fish meal (\%) & 6 & 0 & 6 & 0 & 6 & 0 & 6 & 0 & 6 & 0 & 6 & 0 \\
\hline Gluten meal 60 (\%) & 7 & 0 & 7 & 0 & 7 & 0 & 4 & 0 & 4 & 0 & 4 & 0 \\
\hline Sunflower oil cake (\%) & 0 & 23 & 0 & 23 & 0 & 23 & 0 & 13 & 0 & 13 & 0 & 13 \\
\hline Molasses (\%) & 5 & 5 & 5 & 5 & 5 & 5 & 5 & 5 & 5 & 5 & 5 & 5 \\
\hline Lucerne hay (\%) & 15 & 20 & 15 & 20 & 15 & 20 & 0 & 14 & 0 & 14 & 0 & 14 \\
\hline Oat hulls (\%) & 5 & 0 & 5 & 0 & 5 & 0 & 0 & 0 & 0 & 0 & 0 & 0 \\
\hline $\mathrm{NaOH}$-wheat straw (\%) & 0 & 0 & 0 & 0 & 0 & 0 & 20 & 6 & 20 & 6 & 20 & 6 \\
\hline Salt (\%) & 0.5 & 0.5 & 0.5 & 0.5 & 0.5 & 0.5 & 0.5 & 0.5 & 0.5 & 0.5 & 0.5 & 0.5 \\
\hline Mineral premix (\%) & 1.5 & 1.5 & 1.5 & 1.5 & 1.5 & 1.5 & 1.5 & 1.5 & 1.5 & 1.5 & 1.5 & 1.5 \\
\hline Romensin $200(\%)^{1}$ & 0 & 0 & 0 & 0 & 0 & 0 & 0.01 & 0.01 & 0.01 & 0.01 & 0.01 & 0.01 \\
\hline Morlac (\%) & 0 & 0 & 2.5 & 2.5 & 0 & 0 & 0 & 0 & 2.5 & 2.5 & 0 & 0 \\
\hline Golden flake (\%) & 0 & 0 & 0 & 0 & 2.5 & 2.5 & 0 & 0 & 0 & 0 & 2.5 & 2.5 \\
\hline \multicolumn{13}{|l|}{ Chemical composition } \\
\hline Dry matter (g/kg) & 903 & 909 & 907 & 901 & 879 & 890 & 920 & 920 & 923 & 927 & 915 & 930 \\
\hline Organic matter (g/kg) & 947 & 945 & 940 & 941 & 947 & 945 & 957 & 956 & 953 & 954 & 954 & 955 \\
\hline Crude protein (g/kg) & 173 & 182 & 177 & 176 & 176 & 179 & 141 & 134 & 144 & 137 & 144 & 136 \\
\hline Crude fibre $(\mathrm{g} / \mathrm{kg})$ & 75 & 116 & 81 & 130 & 81 & 139 & 111 & 127 & 105 & 128 & 96 & 125 \\
\hline Ether extract (g/kg) & 47 & 42 & 66 & 48 & 66 & 54 & 37 & 35 & 48 & 46 & 56 & 47 \\
\hline Calculated ME (MJ/kg) & 12.0 & 11.9 & 12.4 & 12.3 & 12.6 & 12.5 & 11.9 & 12.0 & 12.3 & 12.4 & 12.5 & 12.6 \\
\hline
\end{tabular}

Chromium concentration in faecal samples was determined by wet digestion using concentrated sulphuric acid, nitric acid and perchloric acid, followed by an appropriate dilution of 8-hydroxyquinoline to suppress the interference of iron and reduce all of the chromium to the trivalent form. The chromium concentration was then determined by atomic absorption spectrophotometry against calibration standards prepared from pure reference standard chromic oxide (P. Johnson, 1999, personal communication).

At the end of the trial, all the animals were slaughtered in a commercial abattoir. After dressing, the warm carcass weight was recorded and a dressing percentage (warm carcass weight / live weight x 100) calculated.

The data were subjected to an ANOVA using the GLM procedure of SAS (1988). Different contrasts were used to indicate differences between treatments. Three main contrasts were used, viz. fat (supplfat), protein degradability (protdeg) and the interaction between fat and protein degradability, viz. supplfat*protdeg. Supplfat was further subdivided into two contrasts, viz. (i) none vs. fat, i.e. no fat supplementation compared with fat supplementation, ignoring protein degradability and different fat sources, and (ii) mlc vs. gf, i.e. the two fat sources were compared, ignoring protein degradability. In the second contrast (protdeg) the low degradable treatments were compared to the high degradable treatments, ignoring fat supplementation. The interaction between fat and protein degradability (supplfat*protdeg) was further 
subdivided into (i) (none vs. fat)*protdeg, i.e. the interaction of protein degradability with no fat supplementation vs. the interaction of protein degradability with fat supplementation, and (ii) (mlc vs. gf)*protdeg, i.e. the interaction of each fat source with protein degradability.

\section{Results and Discussion}

Although fat inclusion in the diet increased ether extract values (Table 2), these values do not agree with anticipated values. Based on the level of fat inclusion, the ether extract values of mlc and gf diets were expected to be more than two percentage units higher than the control diets. The reason cannot be fully explained, but may be related to a possible poor recovery of fat in the acidified ether.

Mean in sacco CP degradability values in the starter diets were 32.3 and $69.6 \%$ for the low (LD) and high (HD) degradable diets, respectively, and for the finishing diets, the respective values were 23.5 and $52.7 \%$. The expected RDP fraction was calculated before the trial and compared to the RDP fraction determined in situ (Table 3). For the LD treatments, the mean calculated RDP value of the starter diets was $88 \mathrm{~g} / \mathrm{kg} \mathrm{DM}$ and that of the finishing diets $62 \mathrm{~g} / \mathrm{kg} \mathrm{DM}$, while the determined values were $57 \mathrm{and} 34 \mathrm{~g} / \mathrm{kg}$ $\mathrm{DM}$, respectively. For the HD treatments, the mean calculated RDP value of the starter diets was $123 \mathrm{~g} / \mathrm{kg}$ $\mathrm{DM}$ and that of the finishing diets $92 \mathrm{~g} / \mathrm{kg} \mathrm{DM}$, while the determined values were 125 and $72 \mathrm{~g} / \mathrm{kg} \mathrm{DM}$, respectively. Except for the HD starter diets, the RDP fraction was thus overestimated, although the differences between LD and HD diets were bigger than calculated.

Table 3 In sacco crude protein (CP) degradability values and degradable CP content of pelleted veal calf starter and finishing diets containing low (LD) or high (HD) levels of rumen degradable protein (RDP), with or without rumen inert fat sources $($ mlc $=$ Morlac; gf $=$ Golden Flake)

\begin{tabular}{|c|c|c|c|c|c|c|c|c|c|c|c|c|}
\hline \multirow[t]{2}{*}{ Item } & \multicolumn{6}{|c|}{ Starter diets } & \multicolumn{6}{|c|}{ Finishing diets } \\
\hline & LD & HD & $\begin{array}{c}\begin{array}{c}\text { LD } \\
+ \text { mlc }\end{array}\end{array}$ & $\begin{array}{c}\mathrm{HD} \\
+\mathrm{mlc}\end{array}$ & $\begin{array}{l}\text { LD } \\
+\mathrm{gf}\end{array}$ & $\begin{array}{l}\mathrm{HD} \\
+\mathrm{gf}\end{array}$ & LD & $\mathrm{HD}$ & $\begin{array}{c}\mathrm{LD} \\
+\mathrm{mlc}\end{array}$ & $\begin{array}{r}\mathrm{HD} \\
+\mathrm{mlc}\end{array}$ & $\begin{array}{l}\text { LD } \\
+ \text { gf }\end{array}$ & $\begin{array}{l}\mathrm{HD} \\
+\mathrm{gf}\end{array}$ \\
\hline In sacco CP degradability (\% CP) & 31.6 & 70.7 & 29.6 & 63.1 & 35.8 & 74.9 & 23.0 & 48.0 & 21.5 & 63.9 & 25.9 & 46.1 \\
\hline RDP, in sacco (g/kg DM) & 55 & 129 & 52 & 111 & 63 & 134 & 32 & 40 & 31 & 88 & 37 & 63 \\
\hline RDP, calculated (g/kg DM) & 89 & 124 & 88 & 123 & 88 & 123 & 63 & 93 & 62 & 92 & 62 & 92 \\
\hline
\end{tabular}

Table 4 Body weight gain, feed intake (DMI) and feed conversion ratio (FCR) for the different experimental periods and carcass data of calves receiving diets containing low (LD) or high (HD) levels of rumen degradable CP, with or without rumen inert fat sources (mlc = Morlac; gf = Golden Flake)

\begin{tabular}{lcccccccc}
\hline Item & \multicolumn{7}{c}{ Treatments } \\
\cline { 2 - 8 } & LD & HD & $\begin{array}{c}\text { LD } \\
+ \text { mlc }\end{array}$ & $\begin{array}{c}\text { HD } \\
+ \text { mlc }\end{array}$ & $\begin{array}{c}\text { LD } \\
+ \text { gf }\end{array}$ & $\begin{array}{c}\text { HD } \\
+ \text { gf }\end{array}$ & SEM & P \\
\hline Starter period, wk 0-10 & & & & & & & & \\
Body weight gain (kg) & 47.6 & 45.4 & 44.6 & 40.0 & 48.3 & 46.2 & 2.45 & NS \\
Milk replacer DMI (kg) & 19.9 & 19.9 & 19.9 & 19.9 & 19.9 & 19.9 & - & NS \\
Starter pellet DMI (kg) & $92.5^{\mathrm{a}}$ & $87.2^{\mathrm{a}}$ & $79.8^{\mathrm{b}}$ & $76.3^{\mathrm{b}}$ & $86.0^{\mathrm{a}}$ & $89.6^{\mathrm{a}}$ & 3.51 & $<0.05$ \\
Lucerne DMI, wk 5-10 (kg) & $1.8^{\mathrm{a}}$ & $1.1^{\mathrm{a}}$ & $3.0^{\mathrm{a}}$ & $2.5^{\mathrm{a}}$ & $6.0^{\mathrm{b}}$ & $1.4^{\mathrm{a}}$ & 0.27 & $<0.05$ \\
Total DMI (kg) & $114.2^{\mathrm{a}}$ & $108.2^{\mathrm{a}}$ & $102.7^{\mathrm{b}}$ & $98.7^{\mathrm{b}}$ & $111.9^{\mathrm{a}}$ & $110.9^{\mathrm{a}}$ & 4.80 & $<0.05$ \\
FCR (DMI/kg gain) & 2.4 & 2.4 & 2.3 & 2.5 & 2.3 & 2.4 & 0.07 & $\mathrm{NS}$ \\
Finishing period, wk 11-20 & & & & & & & & \\
Body weight gain (kg) & 90.9 & 96.2 & 97.9 & 82.4 & 97.2 & 94.6 & 5.05 & $\mathrm{NS}$ \\
Finishing pellet DMI (kg) & 311.0 & 328.3 & 300.4 & 313.9 & 292.8 & 323.7 & 14.95 & NS \\
FCR (DMI/kg gain) & $3.5^{\mathrm{a}}$ & $3.4^{\mathrm{a}}$ & $3.1^{\mathrm{b}}$ & $3.8^{\mathrm{a}}$ & $3.0^{\mathrm{b}}$ & $3.4^{\mathrm{a}}$ & 0.10 & $<0.05$ \\
Total period, wk 0-20 & & & & & & & & \\
Body weight gain (kg) & 138.4 & 141.6 & 142.5 & 122.4 & 145.5 & 140.7 & 6.12 & $\mathrm{NS}$ \\
Total DMI (kg) & 425.2 & 436.5 & 403.1 & 412.7 & 404.7 & 434.6 & 17.96 & NS \\
FCR (DMI/kg gain) & $3.1^{\mathrm{a}}$ & $3.1^{\mathrm{a}}$ & $2.8^{\mathrm{b}}$ & $3.4^{\mathrm{a}}$ & $2.8^{\mathrm{b}}$ & $3.1^{\mathrm{a}}$ & 0.07 & $<0.05$ \\
Carcass weight (kg) & $88.4^{\mathrm{a}}$ & $92.8^{\mathrm{a}}$ & $92.3^{\mathrm{a}}$ & $80.8^{\mathrm{b}}$ & $90.3^{\mathrm{a}}$ & $91.0^{\mathrm{a}}$ & 2.88 & $<0.05$ \\
Dressing \% & 49.4 & 51.0 & 50.5 & 49.0 & 48.1 & 49.6 & 0.63 & NS \\
\hline
\end{tabular}

${ }^{1} \mathrm{DMI}=$ dry matter intake. For milk replacers, this value was constant and pre-determined

${ }^{\mathrm{a}, \mathrm{b}}$ Means with common superscripts within rows did not differ $(\mathrm{P}>0.05)$ 
Results on body weight gain, feed intake, feed conversion ratios and carcass data are presented in Table 4. The data were divided into three periods: starter period from week 0 to 10 , finishing period from week 11 to 20 and total trial period from week 0 to 20 . No calf mortalities occurred during the trial.

No significant differences between treatments were observed in body weight gain during the starter period, although the mlc vs. gf contrast suggested a strong tendency $(P=0.054)$ towards improved gains for the Golden Flake treatments compared to Morlac. Doppenberg \& Palmquist (1991) reported that increasing the dietary fat content resulted in a lower ADG in ruminating calves but an increased ADG in liquid-fed calves.

There was, however, a significant difference $(\mathrm{P}<0.05)$ in starter pellet and total DMI of calves receiving Morlac compared to the other treatments. The contrast mlc vs. gf indicated that calves receiving Morlac had a lower $(\mathrm{P}=0.035)$ total DMI than those receiving Golden Flake (100.7 kg vs. $111.4 \mathrm{~kg})$, irrespective of protein degradability. The contrast (none vs. fat)*protdeg indicated that calves receiving no fat supplementation had similar intakes to those receiving Golden Flake and that protein degradability of the diets had no significant effect on the total DMI. Morlac therefore appeared to have had a negative effect on feed intake. It might be a palatability effect. Grummer et al. (1990) reported that Megalac, a calcium salt of palm oil fatty acids similar to Morlac, appeared to be much less palatable than other types of protected fats. Although the level of acceptability of the fat sources per se was not determined in the current study, it was observed that calves in the Golden Flake treatments showed more interest in their starter pellets than did calves in the Morlac-treatments.

Dry matter intake may also be affected by fat supplementation having a negative effect on fibre digestion in the rumen (Palmquist \& Jenkins, 1980; Palmquist, 1991). Rumen inert fat sources are usually included in ruminant diets to avoid this effect. Jespersen (1993) evaluated Morlac in vitro and found that the calcium soaps were hydrogenated immediately at the start of fermentation and reached a plateau after approximately 12 hours. However, no digestion of the calcium soaps occurred. Because rumen inert fat sources are not excluded from being hydrolysed or hydrogenated in the rumen, rumen inertness, therefore, simply means that the fat or fatty acid source does not alter or affect rumen fermentation. According to Jenkins \& Palmquist (1984), calcium soaps undergo biohydrogenation even though they have no influence on fibre digestion in ruminants. Wu et al. (1991) found that the net biohydrogenation of unsaturated fatty acids of calcium salts of long chain fatty acids was $~ 50 \%$ and they suggested that calcium soaps were only partially protected from biohydrogenation in the rumen. When animal or vegetable fat was added to the diets of lactating dairy cows, extensive biohydrogenation occurred in the rumen and this was associated with a lower digestibility of total fatty acids in the intestine compared with cows fed diets containing no fat (Wu et al., 1991). Golden Flake is also a calcium salt of palm oil fatty acids, but it contains less C18:1 and C18:2 acids and more C18:0 (Table 1), which means that it would undergo less biohydrogenation than Morlac. However, the digestibility trial (during the finishing phase, Table 5) indicated that fibre digestibility was in fact higher in the Morlac diets than in the Golden Flake diets. A fibre digestion effect on intake would, therefore, not have existed in the current study, which makes the palatability hypothesis more acceptable.

Treatment had no effect on FCR from wk 0-10. Fisher (1980) reported that starter intake was similar for the two protein sources they had investigated, but that it was significantly lower for a diet containing $10 \%$ protected fat compared to either 0 or $20 \%$. Body weight gain was higher for calves on the $20 \%$ protected fat starter than those on the $10 \%$ level. In his study, FCR was improved by protected fats in diets for calves from 43 to 70 days of age. However, Waldern \& Fisher (1978) found no effect on FCR when unprotected tallow was added to calf diets. According to Fisher (1980), these contrasting results would suggest that protected tallow was used more efficiently than unprotected tallow for calves.

In the current study lucerne hay was fed $a d$ lib. in addition to the pelleted starter diet to all six groups from week five through 10. An interaction between fat supplementation and protein degradability was observed for lucerne intake. The contrast (mlc vs. gf)*protdeg indicated a higher $(\mathrm{P}=0.003)$ lucerne intake for the calves receiving Golden Flake when protein degradability was low, but not when it was high (Table 4). The LD diets had a lower average crude fibre content than the HD diets (Table 2). The higher starter and total DMI of the Golden Flake calves vs. Morlac calves would suggest a higher passage rate of digesta from the rumen, which could have resulted in lower fibre digestion. The lower fibre digestibility of the finishing pellets actually observed in the Golden Flake calves (Table 5, discussed later) and the low fibre content of the LD diets could explain the stimulus for higher lucerne intake in the LD + gf group. Poor pellet quality in the Golden Flake treatments could be another reason for higher lucerne intake by calves in the Golden Flake 
treatments. The high fat content of these diets and the physical nature of Golden Flake were responsible for pellets to crumble more readily than those of the other treatments.

No significant differences in total body weight gain or total DMI were observed between treatments for the period 11-20 weeks. There was, however, a significant difference in FCR between treatments. An interaction was observed for FCR between rumen inert fat supplementation and dietary protein degradability. The contrast (none vs. fat)*protdeg indicated an improvement $(\mathrm{P}=0.003)$ in FCR when fat was added to the LD diets, but no effect was observed in the HD diets. An increase in energy density by means of rumen inert fat supplementation, as well as a high quality protein inclusion in the diet can apparently be expected to result in more favourable feed conversion ratios in calves from three months of age. As this was not observed during the first 10 weeks of age, it can be speculated that rumen development was responsible for manifesting the difference observed between the HD and LD diets in the finishing period. It therefore appears that high UDP levels only become important in calf diets after 10 weeks of age. Holtshausen \& Cruywagen (2000) reported a similar conclusion. It should be taken into account, however, that all the calves received milk replacer during the first five weeks of life (i.e. significant levels of bypass protein) which may have shadowed possible effects of starter pellet protein quality.

Regarding the total 20 week experimental period, no significant differences in body weight gain or DMI were observed between treatments. However, feed conversion ratios differed significantly between treatments for certain contrasts. The same tendency as was observed during the finishing period, viz. an interaction between fat supplementation and protein degradability, was also observed for the total experimental period. Again, there were no significant differences between LD and HD when there was no fat supplementation, and the effect of fat $(\mathrm{P}=0.004)$ was only observed when added to the low degradable protein diets.

Fallon et al. (1986) found that the inclusion of low levels of calcium soaps in calf diets may be beneficial in allowing an increase in energy intake without affecting fibre digestibility. However, when the proportion of calcium soap in the concentrate was 0.10 or higher, intake was reduced and $\mathrm{N}$-retention decreased. No data could be found in the literature where Golden Flake was included in calf diets. Three experiments were conducted by Fluharty \& Loerch (1997) to determine the effect of supplemental Megalac (a calcium soap of palm fatty acids) in diets of newly arrived steers. Megalac was supplemented at levels of 0 or $2 \%$ in diets containing either 12 or $14 \%$ CP. Fat supplementation showed no benefit and they concluded that, with high CP concentrations or in diets containing supplemental ruminal escape protein, Ca soaps may be detrimental due to decreased dry matter intake. According to Brandt \& Anderson (1990), however, fat supplementation increased daily gain, feed efficiency and estimated dietary metabolizable energy concentration.

An interaction between fat and protein degradability was observed for carcass weight (Table 4). The contrasts (none vs. fat)*protdeg and (mlc vs. gf)*protdeg indicated that not all fat supplementations were responsible for differences between treatments, but that the interaction pertained to specific fat sources. The effect of fat source was only significant in the high degradable protein diets. Calves receiving Morlac with HD protein diets had lower $(\mathrm{P}<0.05)$ carcass weights than calves in any of the other treatments. These calves also had the lowest body weight gains over the entire experimental period. This could not be explained by DMI, because their total DMI was not the lowest.

Fat supplementation did not increase the dressing percentage in the current trial (Table 4). Gardner \& Wallentine (1972) reported that tallow added to veal calf diets did not improved dressing percentage, a conclusion supported by Fisher (1980). In contrast, Brandt \& Anderson (1990) observed that supplemental fats increased carcass weights and dressing percentages of steers.

Results of the digestibility trial are presented in Table 5. A fat*protein interaction was observed for DM digestibility. The contrast (none vs. fat)*protdeg indicated that DM digestibility was higher in the fat supplemented calves receiving a low degradable CP diet, but that fat had no effect when high degradable CP diets were fed. An explanation for this observation is not apparent, but may be related to a possible improved intestinal protein (amino acid):energy ratio. No relevant literature could be found to compare the data.

Rumen inert fat supplementation had a significant effect on apparent CP digestibility (Table 5). The contrast (none vs. fat) indicated that all diets supplemented with rumen inert fat (regardless of source) manifested a higher apparent CP digestibility ( $\mathrm{P}<0.001$ for LD diets and $\mathrm{P}<0.05$ for HD diets). Fat supplementation resulted in a higher energy density in the diets and possibly resulted in a more favourable energy:protein ratio in the small intestine. The contrast (protdeg) indicated that the level of CP 
degradability also affected CP digestibility, but only when fat was supplemented to the diet. With either of the fat sources, the LD diets resulted in a higher $(\mathrm{P}<0.05)$ apparent $\mathrm{CP}$ digestibility. It could be expected that a significant amount of the protein in the LD protein diets escaped rumen fermentation and would presumably have delivered more essential amino acids to the small intestine.

Table 5 Total tract digestibility values (\%) of nutrients in calf diets containing low (LD) or high (HD) levels of rumen degradable CP, with or without rumen inert fat sources (mlc = Morlac; gf = Golden Flake)

\begin{tabular}{llccccc}
\hline \multirow{2}{*}{ Nutrient } & Dietary CP & \multicolumn{3}{c}{ Fat source } & P(rows) & P(columns) \\
\cline { 2 - 5 } & degradability & None & Morlac & Golden Flake & & \\
\hline \multirow{2}{*}{ Dry matter } & Low & $61.7^{\mathrm{a}}$ & $75.4^{\mathrm{b}}$ & $75.5^{\mathrm{b}}$ & $<0.001$ & NS \\
& High & $65.9^{\mathrm{a}}$ & $69.0^{\mathrm{a}}$ & $67.2^{\mathrm{a}}$ & NS & \\
Crude protein & Low & $61.4^{\mathrm{a}, \mathrm{x}}$ & $71.3^{\mathrm{b}, \mathrm{x}}$ & $75.4^{\mathrm{b}, \mathrm{x}}$ & $<0.001$ & $<0.05$ \\
& High & $61.6^{\mathrm{a}, \mathrm{x}}$ & $68.2^{\mathrm{b}, \mathrm{y}}$ & $66.1^{\mathrm{b}, \mathrm{y}}$ & $<0.05$ & \\
Crude fibre & Low & $33.7^{\mathrm{a}}$ & $53.9^{\mathrm{b}}$ & $32.9^{\mathrm{a}}$ & $<0.001$ & NS \\
& High & $37.4^{\mathrm{a}}$ & $42.5^{\mathrm{b}}$ & $24.9^{\mathrm{a}}$ & $<0.05$ & \\
\multirow{2}{*}{ Fat } & Low & $58.6^{\mathrm{a}}$ & $76.0^{\mathrm{b}}$ & $78.4^{\mathrm{b}}$ & $<0.001$ & NS \\
& High & $66.5^{\mathrm{a}}$ & $70.9^{\mathrm{a}}$ & $70.8^{\mathrm{a}}$ & NS & \\
\hline
\end{tabular}

${ }^{a}$ Row and ${ }^{x y}$ column means with common superscripts do not differ $(\mathrm{P}>0.05)$

Dietary fat supplementation affected crude fibre (CF) digestibility and the contrast (mlc vs. gf) indicated that the effect was related to the source of rumen inert fat. A higher CF digestibility was observed with Morlac than with Golden Flake and the effect was more significant in the LD diets $(\mathrm{P}<0.001)$ than in the HD diets $(\mathrm{P}<0.05)$. Since virtually all of the fibre digestion would occur in the rumen and since neither a rumen protected nor unprotected fat would be expected to enhance ruminal fibre digestion, an explanation for this observation could not be offered. It could be speculated that, because calves on the Morlac supplemented diets had a significantly lower starter pellet intake than the others (Table 4), and because a lower intake is usually associated with a lower passage rate from the rumen and higher fibre digestibility, the explanation could be related to differences in feed intake. However, this would not be convincing because no significant differences in DMI were observed between treatments in the finishing period during which the digestibility trial was executed.

A fat*protein interaction was observed for fat digestibility (Table 5). The contrasts (none vs. fat)*protdeg and (mlc vs. gf)*protdeg indicated that the interaction pertained to fat supplementation, regardless of source. Fat digestibility was higher $(\mathrm{P}<0.001)$ when rumen inert fat was supplemented to the LD protein diets, but not to the HD protein diets. The effect of protein degradability on fat digestibility could not be explained, but could again be related to amino acid quality and energy:protein ratio in the small intestine. Andrew et al. (1991) observed an increase in apparent fat digestibility with increased dietary CP levels in lactating dairy cows, an effect that might have been related to an increased dietary CP flow to the duodenum. Elliott et al. (1995) reported higher apparent fat digestibilities when dairy cows received low NSC diets. They postulated that the effect could be related to greater digestibility of fatty acids from the ingredients that replaced corn.

\section{Conclusion}

Rumen inert fat supplementation and crude protein degradability level (high vs. low) in starter- and finishing diets for veal calves appear to have no effect on body weight gain until 20 weeks of age. Results from the current study would suggest a favourable effect of rumen inert fat supplementation on FCR, but only when included in diets with low protein degradability. The effect appears to manifest only after 10 weeks of age, indicating the role of rumen activity. In low degradable protein diets, it appears as if the UDP fraction of the protein contributes significantly to essential amino acids in the small intestine. Rumen inert fat supplementation to low degradable protein diets probably results in an improved protein to energy ratio in the small intestine of calves older than 10 weeks of age. Neither fat supplementation nor low degradable protein diets alone had any significant effect on calf performance, but in combination a positive effect was observed in terms of feed conversion ratio and nutrient digestibility. Results from this study suggest that protein degradability per se does not appear to affect calf performance until approximately 10 weeks of age. It would therefore appear that less expensive protein sources, such as sunflower oil cake, may replace more 
expensive sources, such as fish meal and maize gluten meal, in calf starter diets. After 10 weeks of age, low degradable protein sources, together with the addition of certain types of rumen inert fat, appear to have a beneficial effect on feed conversion ratio.

\section{Acknowledgements}

The authors wish to acknowledge Maritha van der Rijst for her contribution towards the statistical analyses of the data, Peter Johnson (J. Muller Laboratories, Cape Town) for the chromium analysis and Marine Oils (Cape Town) for financial aid.

\section{References}

Akayezu, J.M., Linn, J.G., Otterby, D.E. \& Hansen, W.P., 1994. Evaluation of calf starters containing different amounts of crude protein for growth of Holstein calves. J. Dairy. Sci. 77, 1982-1989.

Amos, H.E., 1986. Influence of dietary protein degradability and energy concentration on growth of heifers and steers and intraruminal protein metabolism. J. Dairy Sci.. 69, 2099-2110.

Andrew, S.M., Tyrrell, H.F., Reynolds, C.K. \& Erdman, R.A., 1991. Net energy for lactation of calcium salts of long-chain fatty acids for cows fed silage-based diets. J. Dairy Sci. 74, 2588-2600.

AOAC, 1990. Official methods of analysis (15th ed.) Association of Official Analytical Chemists, Washington, DC.

AOAC, 1996. Official methods of analysis (16th ed.) Association of Official Analytical Chemists, Washington, DC.

Bartley, E.E., 1973. Effects of a self-fed pelleted mixture of hay and calf starter on the performance of young dairy calves. J. Dairy Sci. 56, 817-820.

Brandt, R.T., \& Anderson, S.J., 1990. Supplemental fat source affects feedlot performance and carcass traits of finishing yearling steers and estimated diet net energy value. J. Anim. Sci. 68, 2208-2216.

Doppenberg, J. \& Palmquist, D.L., 1991. Effect of dietary fat level on feed intake, growth, plasma metabolites and hormones of calves fed dry or liquid diets. Livest. Prod. Sci. 29, 151-166.

Elliott, J.P., Drackley, J.K. Fahey, G.C. \& Shanks, R.D., 1995. Utilization of supplemental fat by dairy cows fed diets varying in content of nonstructural carbohydrates. J. Dairy Sci. 78, 1512-1525.

Fallon, R.J., Williams, P.E.V. \& Innes, G.M., 1986. The effect on feed intake, growth and digestibility of nutrients including calcium soaps of fat in diets for young calves. Anim. Feed Sci. Technol. 14, 103115.

Fisher, L.J., 1980. Comparison of rapeseed meal and soybean meal as a source of protein and protected lipid as a source of supplemental energy for calf starter diets. Can. J. Anim. Sci. 60, 359-366.

Fluharty, F.L., \& Loerch, S.C., 1995. Effects of protein concentration and protein source on performance of newly arrived feedlot steers. J. Anim. Sci. 73, 1585-1594.

Fluharty, F.L. \& Loerch, S.C., 1997. Effects of concentration and source of supplemental fat and protein on performance of newly arrived feedlot steers. J. Anim. Sci. 75, 2308-2316.

Gardner, R.W. \& Wallentine, M.B., 1972. Fat supplementation grain rations for veal production. J. Dairy Sci. 55, 989-994.

Grummer, R.R., Hatfield, M.L. \& Dentine, M.R., 1990. Acceptability of fat supplements in four dairy herds. J. Dairy Sci. 73, 852-857.

Holtshausen, L. \& Cruywagen, C.W., 2000. The effect of dietary rumen degradable protein content on veal calf performance. S. Afr. J. Anim. Sci. 30, 204-211.

Jenkins, T.C. \& Palmquist, D.L., 1984. Effect of fatty acid or calcium soaps on rumen and total nutrient digestibility of dairy rations. J. Dairy Sci. 67, 978-986.

Jespersen, S.I., 1993. Rumen inert fats for lactating dairy cows. M.Sc.Agric. thesis. University of Stellenbosch, South Africa.

Leibholz, J. \& Kang, H.S., 1973. The crude protein requirement of the early-weaned calf given urea, meat meal or soya bean meal with and without sulphur supplementation. Anim. Prod. 17, 257-265.

Morrill, J.L. \& Dayton, A.D., 1978. Factors affecting requirement and use of crude protein in calf starter. J. Dairy Sci. 61, 940-949.

Morrill, J.L. \& Melton, S.L., 1973. Protein required in starters for calves fed milk once or twice daily. J. Dairy Sci. 56, 927-931. 
Palmquist, D.L., 1991. Influence of source and amount of dietary fat on digestion in lactating cows. J. Dairy Sci. 74, 1354-1360.

Palmquist, D.L. \& Jenkins, T.C., 1980. Fat in lactation rations: review. J. Dairy Sci. 63, 1-14.

SAS, 1988. Statistical Analysis System user's guide (Release 6.03). SAS Institute Inc., Cary, North Carolina.

Schurman, E.W. \& Kesler, E.M., 1974. Protein-to-energy ratios in complete feeds for calves at ages 8 to 18 weeks. J. Dairy Sci. 57, 1381-1384.

Stiles, R.P., Grieve, D.G. \& Gillis, W.A., 1974. Effect of three protein levels with and without added fat on the performance and carcass characteristics of heavy veal calves. Can. J. Anim. Sci. 54, 79-86.

Veen, W.A.G. \& Vahl, H.A., 1984. The influence of the degradability of concentrate protein in the rumen and of the lysine content of the concentrate on growth and feed efficiency in early-weaned calves. Neth. J. Agric. Sci. 32, 107-112.

Waldern, D.E. \& Fisher, L.J., 1978. Effect of steam processed barley, source of protein and fat on the intake and utilisation of starter rations by dairy calves. J. Dairy Sci. 61, 221-228.

Wu, Z., Ohajuruka, O.A. \& Palmquist, D.L., 1991. Ruminal synthesis, biohydrogenation, and digestibility of fatty acids by dairy cows. J. Dairy Sci. 74, 3025-3034. 